Т. О. Перцева, Л. І. Конопкіна, Т. В. Кіреєва, К. Є. Богацька, О. Г. Черкасова, О. В. Мироненко, О. В. Фесенко, Л. А. Ботвінікова, К. О. Бєлослудцева Державний заклад “Дніпропетровська медична академія Міністерства охорони здоров'я України”

\title{
ІНТЕРАКТИВНІ ТЕХНОЛОГІЇ НАВЧАЛЬНО-ПІЗНАВАЛЬНОЇ ДІЯЛЬНОСТІ - ІННОВАЦІЙНІ МЕТОДИКИ ЗМІШАНОГО НАВЧАННЯ
}

\author{
T. O. Pertseva, L. I. Konopkina, T. V. Kireyeva, K. Y. Bogatska, O. G. Cherkasova, \\ O. V. Myronenko, O. V. Fesenko, L. A. Botvinikova, K. O. Belosludceva \\ Dnipropetrovsk Medical Academy, Dnipro \\ INTERACTIVE EDUCATIONAL TECHNOLOGY - INNOVATIVE \\ METHODS OF COMBINED EDUCATION
}

\begin{abstract}
Мета роботи - визначити ефективність впровадження інноваційних технологій у навчальний процес на кафедрі внутрішньої медицини 1 Державного закладу “Дніпропетровська медична академія Міністерства охорони здоров’я України” (ДЗ “ДМА”).

Основна частина. Нові підходи до навчання студентів передбачають активацію творчих здібностей. Творчість передбачає нове бачення, тобто готовність відмовитися від звичних схем викладання навчального матеріалу та готовність до самозмінювання. Одне з найважливіших завдань вищої школи полягає в тому, щоб форми та методи навчання сприяли виявленню творчих здібностей та безперервному самовдосконаленню. Впровадження інноваційних освітніх технологій у рамках вищої медичної школи, у тому числі інтерактивних підходів до навчання студентів, інтернів, у сучасних умовах $є$ важливим кроком, що передбачає активацію їх творчих здібностей, нове бачення проблеми з готовністю відмовитися від звичних схем навчання та готовністю до самозмінювання. Інтерактивні технології також спрямовані на формування мотивації у різні періоди професійного становлення та мають особливо важливе значення у підготовці лікарів, у тому числі інтерністів, для яких навчання $\epsilon$ одним із ключових етапів на шляху становлення самостійного фахівця.

Висновок. Застосування інтерактивних форм навчання серед студентів-медиків ефективно впливає на процес засвоєння ними комплексу клінічних знань, характеризується індивідуалізацією навчальних підходів, є потужним фактором оптимізації навчального процесу, що забезпечує більшу керованість, результативність та ефективність навчання.
\end{abstract}

Ключові слова: інтерактивні технології навчання; професійна мотивація; організація навчального процесу.

The aim of the work - to determine the efficiency of introducing innovative technologies into the educational process at the Department of Internal Medicine 1 of the State Institution "Dnipropetrovsk Medical Academy of the Ministry of Health of Ukraine" (SI "DMA").

The main body. New approaches to student learning envisage the activation of creative abilities. Creativity involves a new vision, that is, the willingness to abandon the usual teaching materials teaching curriculum and readiness for self-transformation. One of the most important tasks of a higher school is that the forms and methods of teaching contribute to the discovery of creative abilities, and continuous self-improvement. The introduction of innovative educational technologies within the framework of a higher medical school - including interactive approaches to teaching students, interns in modern conditions is an important step that involves activating their creative abilities, a new vision of a problem willing to abandon the usual learning schemes and readiness for self-transformation. Interactive technologies are also aimed at creating motivation in different periods of professional development and are especially important in the training of doctors, including internists, for whom training is one of the key stages in the path of becoming an independent specialist.

Conclusion. The application of interactive forms of training among medical students effectively influences on the process of assimilating them to a complex of clinical knowledge, characterized by the individualization of educational approaches, is a powerful factor in optimizing the educational process, which provides greater manageability and efficacy of training.

Key words: interactive learning technologies; professional motivation; organization of educational process.

Вступ. Особливістю вищої медичної освіти сьогодення є те, що викладачі навчальних закладів застосовують різні педагогічні інновації. Втім, так чи інакше, вони торкаються трьох основних напрямів:

(ㄱ Т. О. Перцева, Л. І. Конопкіна, Т. В. Кіреєва та ін. сучасної інфраструктури навчання, яка включає інформаційну, технологічну, організаційну та комунікативну складові; сучасного змісту навчальної дисципліни, який передається учням не стільки для засвоєння предметних знань, скільки для розвитку 
адекватних компетенцій; та сучасних методів навчання - активних методів формування компетенцій, які грунтуються на взаємодії осіб, що навчаються, та на залученні їх до навчального процесу, а не лише до пасивного сприйняття матеріалу. Усе залежить від традицій вузу, від його статусності.

Інноваційні освітні технології - це надзвичайно важливий чинник розвитку людського потенціалу. У найбільш широкому значенні під ними слід розуміти інструменти, які є корисними у процесі навчання [2, 4]. Цими інструментами можуть бути як матеріальні об’єкти (різноманітне обладнання, зокрема мультимедійне, комп’ютерне), так і навчальні системи, способи організації навчання (ігри, майстер-класи, круглі столи, конференції), методи й стратегії. Інноваційні освітні технології спрямовані на підвищення якості освіти. Вони повинні забезпечувати особистісне та професійне зростання педагогів, успішність учнів у навчальнопізнавальній діяльності та оптимізувати життєві, фінансові, часові й кадрові ресурси.

У рамках вищої медичної школи уся ця система інноваційних технологій орієнтована на організацію навчального процесу; підвищення мотивації студентів, лікарів-інтернів, магістрантів, аспірантів та клінічних ординаторів до професійного злету; на дидактичне застосування наукових знань, а також використання емпіричних інновацій викладачів. Зрештою, інноваційні технології дозволяють регулювати навчання, направляючи його на вірний шлях.

Одним із видів інноваційних освітніх технологій $\epsilon$ інтерактивний технологічний проект, що передбачає спільну навчально-пізнавальну діяльність різних груп студентів. Інтерактивність передбачає суб' єкт-суб'єктні відносини в ході освітнього процесу та, як наслідок, формування інформаційно-ресурсного середовища. До таких технологій відносяться лекція зворотного зв'язку (зокрема, такі її типи, як лекція-провокація з викладенням матеріалу із заздалегідь запланованими помилками, лекція-бесіда, лекція-дискусія), семінар-дискусія (з колективним обговоренням будь-якого дискутабельного питання, проблеми) або конференція, де викладання змісту супроводжується презентацією (демонстрацією навчальних матеріалів, що представлені у різних знакових системах, у тому числі в ілюстративних, графічних, аудіо- та відеоматеріалах). Ці інноваційні технології спрямовані на підвищення якості підготовки студентів шляхом розвитку у них творчих здібностей, самостій- ності, передбачають застосування інформаційних технологій та навчально-методичних матеріалів, що відповідають сучасному світовому рівню. Вони зобов’язують студентів самостійно знаходити, переробляти й реалізувати інформацію, представлену у певній дидактичній формі. Подібний вид навчання, на відміну від традиційних, значно збагачує банк знань та водночас підвищує потенціал творчого мислення майбутніх фахівців.

Інтерактивні технології спрямовані на формування мотивації у різні періоди професійного становлення та мають особливо важливе значення у підготовці лікарів, у тому числі інтерністів, для яких навчання є одним із ключових етапів на шляху становлення самостійного фахівця. Для студентів медичних вишів мотивація має два основних аспекти - пізнавальний і професійний.

Мета роботи - визначити ефективність впровадження інноваційних технологій у навчальний процес на кафедрі внутрішньої медицини 1 Державного закладу “Дніпропетровська медична академія Міністерства охорони здоров’я України” (ДЗ “ДМА”).

Основна частина. Співробітники кафедри розробили ідею проведення інтерактивних клінічних конференцій для студентів 4 курсу. Для підготовки й участі у подібних конференціях залучаються як студенти, що вивчають внутрішню медицину українською мовою, так і іноземні студенти, що навчаються англійською. Під керівництвом викладача-куратора студенти готують розбір клінічних випадків.

На підставі зібраних та проаналізованих матеріалів, що стосуються конкретного пацієнта, готуються презентації із залученням графічних, табличних даних, з широким використанням відеоматеріалів. Презентаційний ряд доповідей україномовних студентів доповнюється перекладом на англійську мову та синхронним усним перекладом студентадоповідача з української на англійську. Доповіді іноземних англомовних студентів не супроводжуються ані синхронним перекладом, ані коментарями українською мовою.

Після розбору клінічного випадку студентами зазвичай ініціюється жива дискусія щодо основних питань клінічної симптоматики, диференційної діагностики, підходів до лікування хворих. Звичайно ж, модераторами дискусій є викладачі, які допомагають студентам подолати мовний бар’єр та направити дискусію у потрібне русло. Таким чином, у ході проведення інтерактивної клінічної 
конференції задіюються, з одного боку, потужні фактори інтерактивних навчальних технологій, а з іншого - серйозні мотиваційні механізми як для поглибленого теоретичного вивчення фактичного матеріалу, набуття практичних навичок, так і для поглибленого вивчення іноземної мови, що додатково посилює комунікативно-пізнавальний фон.

Інтерактивні форми проведення семінарських занять.

Інноваційні підходи до навчання студентів у сучасних умовах передбачають активацію їх творчих здібностей, нове бачення проблеми з готовністю відмовитися від звичних схем навчання та готовністю до самозмінювання. Одним із найважливіших завдань вищої школи є й те, щоб форми і методи навчання сприяли розвитку здібностей молодої особи до безперервного самовдосконалення.

У навчальній програмі студентів 4 курсу медичного вузу одним із провідних напрямів є засвоєння практичних навичок при безпосередній роботі з пацієнтами. Це стимулює майбутніх лікарів до активних дій, реалізації їх бажань щодо більш глибокого засвоєння теоретичних знань, дозволяє у подальшому вільно спілкуватися з хворими самостійно. Для виконання цих вимог певна частина кожного заняття з внутрішньої медицини проводиться безпосередньо біля ліжка хворого. Часто досвідчені викладачі (професори, доценти) використовують інноваційну технологію майстер-класу, яка дозволяє студентам закріпити теоретичні знання, долучившись до огляду пацієнта 3 наступним повним обговоренням клінічної ситуації.

Однак на момент вивчення теми не завжди є можливість демонстрації хворого, що має відповідний діагноз. У таких випадках альтернативою стають інші методики практичного опрацювання теми за інноваційними інтерактивними технологіями: ділова гра, консиліум, палатна команда $[1,3,5]$.

Ділова гра - це моделювання реальної діяльності у спеціально створеній проблемній ситуації. Вона $€$ засобом і методом підготовки та адаптації до трудової діяльності та соціальних контактів, методом активного навчання, який сприяє досягненню конкретних завдань, структурування системи ділових стосунків учасників. Її конструктивними елементами $€$ проектування реальності, конфліктність ситуації, активність учасників, відповідний психологічний клімат, міжособистісне та міжгрупове спілкування, розв'язання сформульованих на початку гри проблем. Встановлено, що при подачі матеріалу у такій формі засвоюється близько 90 \% інформації. Активність студентів проявляється яскраво, носить тривалий характер та змушує їх бути активними.

У медичному навчальному закладі семінарське заняття за технологією ділової гри є одним із методів активного навчання та передбачає моделювання клінічної ситуації. Під час ділової гри вирішуються не лише ігрові чи професійні завдання - відбувається навчання i, водночас, професійне виховання студентів. Робота проводиться у навчальній аудиторії. Кожен студент виконує певну роль у грі, яка обирається шляхом жеребкування. Такий рандомізований підхід дозволяє більш об' єктивно оцінити ступінь теоретичної підготовки кожного студента. Пропонується попередній діагноз, який відповідає нозології, що розглядається на практичному занятті. У групі визначаються такі ролі, як хворий, лікар терапевтичного відділення, лікар відділення функціональної діагностики, лікар-лаборант, фармацевт. За потребою додаються ролі медичної сестри, лікаря-фізіотерапевта, родича, завідувача відділення. Студенти, які не входять до основної групи навчання, мають змогу корегувати кожного з учасників лікувально-діагностичного процесу як експерти або фахівці-консультанти. Наприкінці ділової гри викладач зазвичай озвучує повний клінічний діагноз, а консиліум вирішує, з яким діагнозом виписується хворий та чи правильно він був сформульований, на якому етапі було скореговано діагноз та чи були допущені помилки.

Майже усі студенти після подальшого їх опитування відзначили, що під час проведення ділової гри почували себе розкутіше, ніж з реальними хворими. Така методика проведення заняття дозволила їм у подальшому навчитися вільніше спілкуватися 3 пацієнтами.

Отже, ділова гра є ефективним педагогічним інструментом інноваційного навчання, що направлений на формування клінічного мислення, та може бути рекомендований як альтернативна форма аудиторної роботи зі студентами.

За технологією консиліуму на початку семінарського заняття студенти отримували тематичного хворого для курації та його історію хвороби з результатами додаткових методів досліджень. Обирали нозологічні форми, що відповідали тематиці заняття (пневмонія, хронічне обструктивне захворювання легень, бронхіальна астма, гіпертонічна хвороба тощо). Усі студенти групи мали однакове завдання, втім працювали індивідуально. У разі необхідності вони отримували додаткову інформацію 
від викладача. Після закінчення роботи кожний студент у присутності колег формулював попередній діагноз, підтверджуючи його даними додаткових методів досліджень, захищав свою думку, вступав у полеміку, вчився коректно вести дискусію. Питання лікування або первинної чи вторинної профілактики обговорювали усі студенти разом під керівництвом викладача.

Запропонована методика за технологією консиліуму дозволяла виявити рівень знань та умінь кожного студента, є мотивацією для опанування додаткової літератури за темою. При такій формі інтерактивного подання та засвоєння матеріалу підвищується рівень формування клінічного мислення студента, він навчається висловлювати свою думку у колі колег та підкріплювати ї̈ літературними даними.

Навчання англомовних студентів на кафедрі внутрішньої медицини 1 відбувається вже понад 17 років. Застосування різних методик навчання для них є досить ефективним, втім мовний бар’єр, культурно-етнічні відмінності викликають певні труднощі при роботі з хворими. Для їх подолання на кафедрі був впроваджений досвід палатних ко-

\section{Список літератури}

1. Айламазьян А. М. Актуальні методи виховання i навчання: ділова гра / А. М. Айламазьян. - М. : Владоспрес, 2000.

2. Дичківська I. М. Інноваційні педагогічні технології / І. М. Дичківська. - К. : Академвидав, 2004. - 218 с.

3. Коломієць В. С. Ігри в структурі професійної підготовки : зб. наук. праць / В. С. Коломієць ; за ред. А. Й. Капської. - К., 1999. - С. 153-160.

\section{References}

1. Ailamazian, A.M. (2000). Aktualni metody vykhovannia i navchannia: dilova hra [Actual methods of education and training: business game]. Moscow: Vlados-pres [in Ukrainian].

2. Dychkivska, I.M. (2004). Innovatsiini pedahohichni tekhnolohii [Innovative pedagogical technologies]. Kyiv: Akademvydav [in Ukrainian].

3. Kolomiiets, V.S. (1999). Ihry v strukturi profesiinoi pidhotovky: $\mathrm{Zb}$. nauk. prats [Games in the structure of professional training: collection of scientific works]. Kapska, A.Y. (Ed.). Kyiv [in Ukrainian]. манд, до складу яких, крім студента, входили лікарінтерн та/або клінічний ординатор. Загальну координаційну роботу, звичайно, здійснював викладач.

Основними мотивами роботи палатної команди є бажання опанувати професійні навички та вміння, поглибити на практиці отримані теоретичні знання, відпрацювати стандарти надання медичної допомоги, отримати досвід практичної роботи, що дозволить сьогоднішньому студентові у майбутньому успішно працювати самостійно. Основними принципами такої технології роботи є персоналізація студента, взаємодопомога й підтримка, безперервний обмін інформацією, сумісний її аналіз.

Висновок. Застосування інтерактивних форм навчання серед студентів-медиків ефективно впливає на процес засвоєння ними комплексу клінічних знань, характеризується індивідуалізацією навчальних підходів, є потужним фактором оптимізації навчального процесу, що забезпечує більшу керованість, результативність та ефективність навчання.

4. Новолокова Н. П. Енциклопедія педагогічних технологій та інновацій / Н. П. Новолокова. - Х. : Основа, 2012. - 176 c.

5. Носаченко I. М. Диференційований підхід до навчання учнів за допомогою ігрових методів : наук.-метод. зб. / відповід. ред. Н. Г. Ничкало. - К. : НДІ педагогіки, 1992. - 174 с.

4. Novolokova, N.P. (2012). Entsyklopediia pedahohichnykh tekhnolohii ta innovatsii [The encyclopedia of pedagogical technologies and innovations]. Kharkiv: “Osnova” [in Ukrainian].

5. Nosachenko, I.M. (Ed.) (1992). Dyferentsiiovanyi pidkhid do navchannia uchniv za dopomohoiu ihrovykh metodiv: nauk.-metod. $\mathrm{zb}$. [Differentiated approach to teaching students through game techniques: scientific method. save]. Kyiv: NDI pedahohiky [in Ukrainian]. 